\title{
Addressing the Challenges of Ammonia Loss from Poultry Droppings through Indigenous Carbon Wastes
}

\author{
Prasanthrajan Mohan and Boomiraj Kovilpillai
}

\begin{abstract}
Laboratory experiment was conducted to screen the carbonaceous wastes suitable for making poultry droppings compost. Carbon-rich waste materials namely, coir pith, sawdust, paper wastes, leaf litter and paddy straw were evaluated for their efficacy in reducing the ammonia volatilization from poultry droppings. Among the carbon wastes tested, coir pith, saw dust and paddy straw were found to be efficient in reducing the ammonia loss by 31 to 48 per cent. In the compost mix, major nutrients like nitrogen, phosphorus and potassium were increased with the advancement of composting. The coir pith mixed poultry compost recorded high nitrogen $\left(19.7 \mathrm{~g} \mathrm{~kg}^{-1}\right)$ and potassium content $\left(13.9 \mathrm{~g} \mathrm{~kg}^{-1}\right)$, whereas, coir pith and rock phosphate (RP) mixed poultry compost recorded high phosphorus content $\left(20.1 \mathrm{~g} \mathrm{~kg}^{-1}\right)$. When poultry waste was composted without mixing any carbon wastes, it recorded high conductivity (EC) ( $\left.3.63 \mathrm{dS} \mathrm{m}^{-1}\right)$, whereas the poultry waste mixed with coir pith and paddy straw recorded low conductivity value. The carbon and $\mathrm{C} / \mathrm{N}$ ratio of the compost got reduced with the advancement of composting. The cumulative loss of ammonia was more when poultry manure composted without carbon wastes $\left(1125.8 \mathrm{mg} \mathrm{kg} \mathrm{g}^{-1}\right)$. Mixing of poultry wastes with coir pith reduced the ammonia loss by 57.7 percent.
\end{abstract}

Index Terms-Ammonia loss, composting, carbonaceous wastes, poultry droppings.

\section{INTRODUCTION}

In poultry manure a large proportion on nitrogen is present in the form of uric acid and urea [1]. The uric acid and urea are rapidly hydrolyzed to ammonia and carbon dioxide by the enzymes urease and uricase and more than $60 \%$ of ammonia can be subsequently lost through volatilization [2]. Not only does the loss of ammonia reduce the nutrient value of the manure, but levels of ammonia exceeding $25 \mathrm{ppm}$ in the poultry shed may lead to various respiratory and other problems which would affect the bird's growth [1]. The nitrogen in the poultry manure can be conserved either by inhibiting the hydrolysis of uric acid to ammonia or by reducing the ammonia volatilization. Some of the chemicals like formaldehyde and yucca saponin were also found to reduce uric acid hydrolysis but the usage of chemicals may affect the nitrification process and render the poultry manure unsuitable for composting. Mixing poultry manure with carbon rich waste materials will also reduce the ammonia loss by temporary immobilization of $\mathrm{NH}_{4}$ ions. In an earlier study it was reported that the bedding material viz., paddy straw, wood chips and peat were found to be efficient in reducing

Mauscript received January 16, 2012, revised May 29, 2012.

Prasanthrajan Mohan is with the Department of Environmental Science, Tamil Nadu Agricultural University, Coimbatore, 641003, Tamil Nadu, India (e-mail: prasanth_phd@yahoo.co.in).

Boomiraj Kovilpillai is with the Agricultural Research Station, Kovilpatti, 628 501, Tamil Nadu, India (e-mail: boomiraj1@gmail.com). the ammonia loss during composting [1].

Rice husk and saw dust are the most commonly used litter material for raising poultry birds. However, due to diversified industrial uses of these materials, its availability is shrinking. Besides, cost of these litter materials is also increasing day by day. It is therefore necessary to explore the possibility of using alternate litter materials. Sawdust, coir pith, paddy straw, paper waste and leaf litter are rich in carbon and generated in large quantities. Nearly 80 per cent of the above said carbon wastes are dumped in open space causes environmental pollution. These wastes are available near our door step or farm land with high $\mathrm{C} / \mathrm{N}$ ratio and are capable of decreasing the $\mathrm{NH}_{3}$ loss from poultry droppings [2]. Also, addition of rock phosphate during composting of poultry manure decreases the loss of nitrogen through immobilization of nitrogen by forming of ammonium complexes with rock phosphate besides the concept of composting has always been rooted in a soil conservation philosophy that recognizes the role of organic matter in agriculture. The paradox has been that the recent rise in composting interest has come from the need for waste management solutions which emphasize economical and environmental alternatives and not from the need for soil improvement and nutrient cycling. As the availability of carbonaceous wastes viz., sawdust, coir pith, paddy straw, paper waste and leaf litter are plenty, the present investigation was undertaken to solve the ammonia problem of poultry manure and disposal problem of carbonaceous wastes.

\section{EXPERIMENTAL METHODS}

The different carbonaceous waste materials viz., saw dust, coir pith, paddy straw, paper waste and leaf litter (Peltoforum ferrugenum) were collected, air dried, powdered and sieved through $2 \mathrm{~mm}$ sieve for further chemical analysis. Various parameters namely, moisture content, $\mathrm{pH}, \mathrm{EC}$, organic carbon, total nitrogen, total phosphorous, total potassium, cellulose, lignin, sulphur and micronutrients were analyzed by following standard analytical methods. Fresh poultry droppings were collected from caged pit poultry system and mixed with different carbonaceous waste materials. The treatment details are as follows. $\mathrm{T}_{1}$ - Poultry droppings (250 g), $T_{2}$ - Poultry droppings (125 g) + sawdust (125g), $T_{3}$ Poultry droppings $(125 \mathrm{~g})+$ coir pith (187.5 g), $\mathrm{T}_{4}$ - Poultry droppings (125 g) + paddy straw (156.3 g), $\mathrm{T}_{5}$ - Poultry droppings (125 g) + paper waste (156.3 g), $\mathrm{T}_{6}$ - Poultry droppings (125 g) + leaf litter (187.5 g). Treatments were replicated for four times. The $\mathrm{C} / \mathrm{N}$ ratio of the different compost mixes was adjusted to 25 - 30: 1 , which is considered to be an ideal $\mathrm{C} / \mathrm{N}$ ratio for composting, by mixing the poultry droppings with carbon source in different 
quantities and incubated for about 60 days at room temperature. Moisture content of the compost mix was maintained at 60 per cent. Both aerobic and anaerobic experimental setup was maintained for comparison. Incubation experimental results confirmed that the carbonaceous waste materials namely, coir pith, saw dust and paddy straw, were found to be superior in minimizing the ammonia loss.

With the findings of incubation experiment, coir pith and paddy straw were selected for further study as they are available in large quantities. Saw dust was eliminated due to its high cost and poor availability. Poultry droppings along with carbonaceous waste materials namely, paddy straw and coir pith were mixed as per the treatment combinations, $\mathrm{T}_{1}$ Poultry droppings (2 kg), $\mathrm{T}_{2}$ - Poultry droppings $(1 \mathrm{~kg})+$ Paddy straw (1.25 kg), $\mathrm{T}_{3}$ - Poultry droppings (1 kg) + Coir pith $(1.5 \mathrm{~kg}), \mathrm{T}_{4}$ - Poultry droppings $(1 \mathrm{~kg})$ + Paddy straw $(0.625 \mathrm{~kg})+$ Coir pith $(0.750 \mathrm{~kg}), \mathrm{T}_{5}$ - Poultry droppings (1 $\mathrm{kg})$ + Paddy straw (1.25 kg) + Rock phosphate (RP), $\mathrm{T}_{6}$ Poultry droppings $(1 \mathrm{~kg})+$ Coir pith $(1.5 \mathrm{~kg})+\mathrm{RP}, \mathrm{T}_{7}-$ Poultry droppings (1 kg) + Paddy straw (0.625 kg) + Coir pith $(0.750 \mathrm{~kg})+\mathrm{RP}$. The $\mathrm{C} / \mathrm{N}$ ratio of the mixes was 25.4 to 28.1:1. In order to test the practical feasibility, these seven treatments $\left(T_{1}\right.$ to $\left.T_{7}\right)$ were tested under bench scale (laboratory condition) and large scale composting (field condition). Low grade Udaipur Rock Phosphate (RP), manufactured by Rajasthan state mines and minerals limited, was added @ $2.5 \mathrm{~kg} 100 \mathrm{~kg}^{-1}$ of substrate to enrich the compost mix. Poultry droppings and paddy straw were obtained from Tamil Nadu Agricultural University (TNAU) poultry unit and central farm, Coimbatore, Tamil Nadu, India. The coir pith was collected from nearby coir industry located at Pollachi, Tamil Nadu, India.

\section{A. Bench Scale Composting}

The raw materials were placed inside of the compost chamber as per the treatment combinations $\left(T_{1}\right.$ to $\left.T_{7}\right)$. A model diagrammatic representation of the composting system reported in the past research was modified and used in this study is depicted in Fig. 1[4]. The compost chamber consist of an air tight, wide mouth (10 cm wide) plastic jar with two plastic screens (1 mm mesh opening) placed at $5 \mathrm{~cm}$ from the bottom of the jar which formed a false floor. Aeration was provided through $5 \mathrm{~mm}$ opening in the bottom of the compost chamber. The $\mathrm{NH}_{3}$ and $\mathrm{CO}_{2}$ in the air were stripped off by passing it through a container filled with $3 \mathrm{~N}$ boric acid and $3 \mathrm{~N} \mathrm{NaOH}$ and the flow rate was measured using Rota meter. To avoid moisture losses during composting and the consequent inhibition of the composting process, the air entering the compost chamber was humidified by bubbling into deionized water and the air flow rate was adjusted to provide twice as much oxygen uptake rate observed in preliminary experiments. The air flow rate to each composter was set to approximately $100 \mathrm{ml} /$ min during first 20 days and $50 \mathrm{ml} / \mathrm{min}$ there after. The exhaust gas from the compost chamber was passed through a needle valve and then flowed into $50 \mathrm{ml}$ of $3 \mathrm{~N}$ boric acid and $3 \mathrm{~N} \mathrm{NaOH}$ for trapping $\mathrm{NH}_{3}$ and $\mathrm{CO}_{2}$ respectively. Then the samples were used for analyzing $\mathrm{NH}_{3}$ and $\mathrm{CO}_{2}$. Periodical compost samples were drawn from the compost chamber, air dried and analyzed for various parameters namely, $\mathrm{pH}, \mathrm{EC}$, total carbon, total $\mathrm{N}$, $\mathrm{NH}_{4}-\mathrm{N}, \mathrm{NO}_{3}-\mathrm{N}$, cellulose and lignin.

\section{B. Large Scale Composting}

A large scale composting experiment was conducted at TNAU compost yard as per the treatment combinations. $\mathrm{T}_{1}$ Poultry droppings (1000 kg), $T_{2}$ - Poultry droppings (500 kg) + Paddy straw (625 kg), $\mathrm{T}_{3}$ - Poultry droppings (500 kg) + Coir pith (750 kg), $\mathrm{T}_{4}$ - Poultry droppings (500 kg) + Paddy straw (312.5 kg) + Coir pith (375 kg), $\mathrm{T}_{5}$ - Poultry droppings $(500 \mathrm{~kg})+$ Paddy straw (625 kg) + Rock phosphate (RP), $\mathrm{T}_{6}$ - Poultry droppings (500 kg) + Coir pith $(750 \mathrm{~kg})+\mathrm{RP}, \mathrm{T}_{7}-$ Poultry droppings (500 kg) + Paddy straw (312.5 kg) + Coir pith $(375 \mathrm{~kg})+\mathrm{RP}$. Moisture content of the compost heap was maintained at 60 per cent for the entire period of

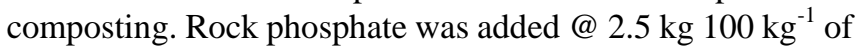
substrate. Periodical samples were drawn from the compost mix, processed and physical, chemical and biological parameters were analyzed by following standard analytical methods. The experimental data were statistically analyzed to determine the influence of various treatments on composting. The differences between treatment means were tested for significance using analysis of variance.

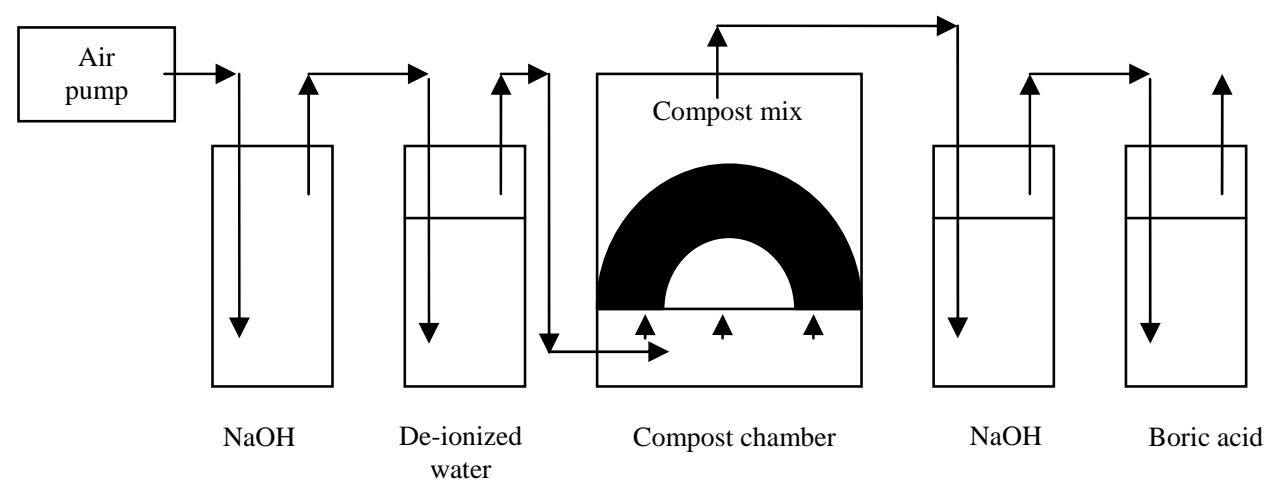

Fig. 1. Bench scale compost system 


\section{RESUlts AND DisCUSSION}

\section{A. Changes in Compost Parameters during Bench Scale Composting}

The $\mathrm{pH}$ of the different mixes were ranged from 6.8 to 7.4 during the early stage of composting and 7.5 to 8.0 during the maturity phase ie. at the end of composting process. There were no further changes in the compost quality parameters at the end of composting hence this period was noted as maturity phase. The rise in $\mathrm{pH}$ during $30^{\text {th }}$ day ranged from 8.1 to 8.9 and this might be due to the loss of ammonia and the reduction of uric acid in the manure. The $\mathrm{pH}$ reduction during the maturity phase is due to the production of organic acid during the decomposition process. In general, the electrical conductivity of the compost mix was increased. The increase in EC could be attributed to the release of soluble salts during decomposition. Total carbon content of the different compost mixes showed a declining trend whereas the total nitrogen content of the compost mixes showed an increasing trend (Table I). Addition of paddy straw and coir pith in poultry manure adds air voids and allow aerobic decomposition of the mixture. Also these waste materials are capable of immobilizing the $\mathrm{NH}_{4}{ }^{+}$ions and thereby reducing the ammonia loss. The total nitrogen content of fresh droppings was $312 \mathrm{~g} \mathrm{~kg}^{-1}$ at the beginning and reduced to $160 \mathrm{~g} \mathrm{~kg}^{-1}$ during $60^{\text {th }}$ day of composting. The reduction in nitrogen content is due to loss of nitrogen in the form of ammonia. Poultry droppings mixed with different carbon waste material recorded high total nitrogen. Coir pith added poultry compost recorded more total nitrogen (199 g $\mathrm{kg}^{-1}$ ) which indicates that the coir pith was more effective in reducing the $\mathrm{NH}_{3}$ loss when compared to paddy straw.

In general, $\mathrm{NH}_{4}-\mathrm{N}$ was increased in all the treatments and organic-N was decreased (Table II). The net rate of conversion of organic nitrogen to $\mathrm{NH}_{4}{ }^{+}-\mathrm{N}$ (ammonification) and $\mathrm{NH}_{4}{ }^{+}$to $\mathrm{NO}_{3}$ (nitrification) were greater but nitrification was slow because the fresh poultry manure contains high density of ammonifiers, which are responsible for the ammonification taking place continuously [6]. Continuous release of $\mathrm{NH}_{3}$ from the manure can also be toxic to nitrite-oxidizing bacteria [7]. Calculation of the nitrogen mass balance from each treatment suggests that some of the $\mathrm{NO}_{3}-\mathrm{N}$ would have been lost through denitrification. The carbonaceous waste material had a significant effect on both ammonification and nitrification under aerobic systems. These nitrogen-poor carbonaceous materials are capable of immobilizing inorganic $\mathrm{NH}_{4}^{+}$ions into organic form and thereby reduce the potential for volatilization loss. The $\mathrm{NH}_{4}-\mathrm{N}$ and $\mathrm{NO}_{3}-\mathrm{N}$ contents were higher in the presence of carbonaceous waste materials than in their absence [1]. Addition of coir pith immobilized more nitrogen than paddy straw. During the initial seven days of incubation the loss of ammonia was high and declined thereafter. Paddy straw reduced the $\mathrm{NH}_{3}$ loss by 33.69 per cent and coir pith 57.7 per cent. Similar observation that the 33 per cent coir treated manure had reduced $\mathrm{NH}_{3}$ volatilization by 48 per cent [7], at the end of 50 days composting period, this may be due to the thick layer of coir pith that affected manure decomposition and hence ammonia emission and also some adsorption may have occurred. It is also possible that some of the carbon in the coir pith was available for bacteria, which may have resulted in nitrogen immobilization. It appears that coir pith and paddy straw were successful in minimizing ammonia emission, particularly during the first few days of composting.

\section{B. Changes in Compost Parameters during Large Scale Composting}

The $\mathrm{pH}$ of the fresh poultry droppings was 6.9. The $\mathrm{pH}$ of the other treatment mix ranged from 7.2 to 7.6. A slight drop in $\mathrm{pH}$ value during the beginning of the composting process is due to accumulation of organic acids. Soon after, the acids were utilized as substrates by other aerobic microbes, the $\mathrm{pH}$ was increased. This increase in $\mathrm{pH}$ was mainly due to the loss of $\mathrm{NH}_{3}$ and reduction in uric acid content. The hydrolysis reactions result in elevated $\mathrm{pH}$ levels that facilitate $\mathrm{NH}_{3}-\mathrm{N}$ volatilization [3]. During the cooling and maturation stages the $\mathrm{pH}$ dropped close to neutral values and then stabilized. This pattern is typical for composting process. The sum of soluble ions in the water extracts, as indicated by EC measurements, increased slightly at the beginning of composting and continued till maturity. The increase in EC is due to the release of easily decomposable compounds into the solution. During the maturation, the EC increased sharply in the solution reaching a maximum of $3.63 \mathrm{dS} \mathrm{m}^{-1}$ in the control and other treatments recorded lower EC values. Ions that contributed to increase in $\mathrm{EC}$ were $\mathrm{NO}_{3}{ }^{-}, \mathrm{Ca}^{2+}, \mathrm{Mg}^{2+}$ and P.

As a variety of carbon compounds are available to microbes (eg. soluble sugars, hemi cellulose, amino acids and proteins) and these were degraded during the thermophilic stages of decomposition and transformed into either $\mathrm{CO}_{2}$ or insoluble, stable organic matter resulting in carbon reduction. The initial carbon content of different compost mixes ranged from 430.7 to $465.3 \mathrm{~g} \mathrm{~kg}^{-1}$ which was 196.4 to $257.0 \mathrm{~g} \mathrm{~kg}^{-1}$ during the maturity of composting. The initial total $\mathrm{N}$ content of the poultry droppings was $30.2 \mathrm{~g} \mathrm{~kg}^{-1}$ and other carbon source added mix had 16.3 to $16.6 \mathrm{~g} \mathrm{~kg}^{-1}$ of total $\mathrm{N}$. This reduction in total nitrogen content is due to the dilution caused by the addition of carbonaceous waste materials [1]; [7]. A greater loss in nitrogen content was recorded in poultry droppings and losses continued up to 21 days. This drop in total nitrogen content at the beginning is due to the loss of nitrogen in the form of ammonia. Coir pith and paddy straw added poultry compost had a slight drop in total nitrogen content which is due to loss of ammonia from the mix during the initial days. During $14^{\text {th }}$ day of composting, the total nitrogen content of the mix was increased. It indicated that there was no further loss of ammonia. The increase in total nitrogen content is because of the presence of same quantity of nitrogen in the reduced volume of the compost mix (Table III). The $\mathrm{C} / \mathrm{N}$ ratio of the compost mix ranged from 11.9 to 13.6 during the maturity phase. The rate of mineralization of organic nitrogen depends greatly on the initial $\mathrm{C} / \mathrm{N}$ ratio and on the type of carbon compounds present. The reduction in $\mathrm{C} / \mathrm{N}$ ratio was due to the decrease in the carbon content which was utilized as energy source for the micro flora and consequently converted into nitrogen content [7].

The highest phosphorus content was recorded in rock phosphate added poultry droppings, coir pith compost (20.1 g 
$\left.\mathrm{kg}^{-1}\right)$. The composting of the waste materials with rock phosphate has been practiced widely as a low input technology in improving the fertilizer value of the manure [5] The organics may provide a sink for the Ca dissolved from rock phosphate by chelating $\mathrm{Ca}$. In general the rock phosphate added compost recorded high phosphorus content. It has been claimed that composting manure with rock phosphate enhances the dissolution of rock phosphate [6]. Initial potassium content of the compost mix ranged from 11.2 to $12.4 \mathrm{~g} \mathrm{~kg}^{-1}$ and 12.1 to $13.9 \mathrm{~g} \mathrm{~kg}^{-1}$ during the maturity phase. At the end of composting period, the nitrogen, phosphorus and potassium contents were high in coir pith added poultry compost when compared to other compost mix The increased moisture content, low electrical conductivity and neutral $\mathrm{pH}$ of the compost established the superiority of coir pith added poultry composts. Coir pith added poultry droppings compost recorded high nitrogen with low $\mathrm{C} / \mathrm{N}$ ratio where as coir pith and paddy straw added in combination recorded comparatively lesser nutrients and high $\mathrm{C} / \mathrm{N}$ ratio. This may due to the heterogeneous nature of the compost mix [7]. The loss of carbon as $\mathrm{CO}_{2}$ from the compost heap varied from 4.6 to $5.4 \mathrm{mg}$ of $\mathrm{CO}_{2} 100 \mathrm{~g}^{-1}$ of dry compost during initial period of composting. The $\mathrm{CO}_{2}$ release increased up to $28^{\text {th }}$ day and declined thereafter. All the treatments caused greater $\mathrm{CO}_{2}$ production than control (poultry droppings compost). The trend in $\mathrm{CO}_{2}$ evolution indicates the microbial activity and rate of decomposition (Table IV).

\section{Changes in Enzyme Activities}

As microorganisms are important sources of enzymes, the activities of these enzymes correlate with microbial activity. Enzymatic activity has a significant correlation with organic matter. The enzyme activities largely reflect the diversity of microbial population. It helps the organisms in their efforts to satisfy their nutritional needs and in their function of degrading and humifying organic materials.

In an earlier study it was reported that the count of mesophilic bacteria remained essentially constant whereas the thermophilic population increased during the thermophilic period. The thermophilic bacterial population was high at $67^{\circ} \mathrm{C}$ during $35^{\text {th }}$ day which suffered a rapid drop afterwards. They consequently appear to play a major role during the cooling period of the process [11]. Most of the organic wastes and crop residues contain different group of microorganism viz., bacteria, fungi and actinomycetes that can contribute significantly to the composting process. Mesophilic bacteria and fungi initiate the composting process at temperature range of $20^{\circ} \mathrm{C}$ to $40^{\circ} \mathrm{C}$ which will rapidly breakdown the soluble and readily degradable compounds. In general, in the first two weeks the composting process was carried out by fungi followed by mesophilic and thermophilic bacteria. During the later stage, mesophilic bacteria and actinomycetes played a major role in the composting process. As the temperature rises, the thermophiles (temperature above $45^{\circ} \mathrm{C}$ ) takes over and breakdown the proteins, fats and complex carbohydrates like cellulose and hemi cellulose. As the supply of these high energy compounds becomes exhausted, mesophilic microorganisms are once again take over for the final phase of maturation of remaining organic matter [7]. Cellulase, infact, is a complex of at least three distinct enzymes with specific activities [12] and has a degradative function of prime importance during the composting process [5]. The enzyme activity increased during mesophilic period declined during thermophilic period and increased again in the late cooling period.

Invertase role is restricted to the break down of disaccharides useful for microbial nutrition and hence it must be considered as an indication of general microbial numbers during the process. Its activity increased during the mesophilic period of composting and reached its highest level during the thermophilic period and subsequently declined to a constant value [6]. Phosphatase and urease are recognized as very important enzymes involved in the composting process. The phosphatase enzymes play an important role in the use of alternative phosphorus sources and considered as a general index of microbial activity in compost. Phosphatase activity increased up to $30^{\text {th }}$ day of composting and declined thereafter (Table V). In general, rock phosphate added compost recorded more phosphatase activity. The urease activity was present at a high level at the beginning of composting process but declined rapidly to a constant low level [7]. This pattern is probably inherent to the nature of the starting material which is rich in excreted urea. This medium is thus favourable for the development of an ureolytic flora which later disappears or stops producing enzymes when urea becomes exhausted.

\section{Biomaturity of Compost}

Biomaturity of compost is essential for its optimal use as a soil amendment and as a source of plant nutrients. Immature compost poses problems of obnoxious odour, flies during storage, bag-bursting during marketing, phytotoxicity and pollution during use, etc. Proper composting results in conversion of nitrogen and transformation of carbon in wastes to $\mathrm{CO}_{2}$ and humic substances. The ideal $\mathrm{C} / \mathrm{N}$ ratio of mature compost is therefore about 10 , as in humus. The $\mathrm{C} / \mathrm{N}$ ratio of the final matured compost ranged from 11.9 to 13.6. As the aerobic composting process progresses, the microbial activity declines, resulting in less oxygen consumption and consequently less $\mathrm{CO}_{2}$ is produced. The respiration rate in matured compost is significantly lower than that in starting raw mix. Temperature drop in the compost mix is also an indication of compost maturity. In general, all the treatments recorded a temperature drop after $35^{\text {th }}$ day and continued up to $60^{\text {th }}$ day of composting.

The smell of mature compost to a significant degree is a function of the microorganisms (i.e. Actinomycetes) that have colonized once again in the compost after peak heating. Maturity is best assessed with plant growth. In immature compost, water-soluble organic compounds seem to inhibit plant growth over that affected by competition for nutrients and oxygen. Phytotoxic compounds and competition for oxygen in the immature compost are assumed to be responsible for the inhibition of plant growth.

Phytotoxicity test were conducted with six different seeds viz., maize, sunflower, black gram, green gram, chilli and radish seeds. In general, all the plants were inhibited by immature compost and in matured compost, usually the growth is improved. Low molecular weight, organic acids (acetic, propionic and butyric) were found to be the most toxic compounds during the early stage of composting. In 
addition immature compost may induce oxygen and nutrient deficiencies in the root zone due to high rates of decomposition. As confirmed in this study, appropriate curing is therefore essential to stabilize compost and eliminate or reduce negative plant responses. Among the crop seeds tested for phytotoxicity, all the crop seeds showed very good germination in all the seven compost mix. Germination percentage ranged from 75 to 100 per cent with maize, 80 to 90 per cent with sunflower, 70 to 85 per cent with chillies, 90 to 100 per cent with black gram, 95 to 100 per cent with green gram and 65 to 85 per cent for radish seeds. The quality of the compost was analyzed which was found to confirm the norms prescribed. The mature compost was black in colour with no obnoxious odour and with good stability which would no longer generate high temperatures. The $\mathrm{pH}$ values of matured compost ranged from 7.4 to 7.8. Irrespective of the source of composting substrate, the $\mathrm{C} / \mathrm{N}$ ratio of matured compost ranged from 11.9 to 13.6 .

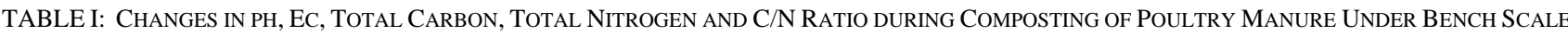
COMPOSTING

\begin{tabular}{|c|c|c|c|c|c|c|c|c|c|c|c|c|c|c|c|}
\hline \multirow[b]{2}{*}{ Treatments } & \multicolumn{3}{|c|}{$\mathrm{pH}$} & \multicolumn{3}{|c|}{$\mathrm{EC}(\mathrm{dS} \mathrm{m}-1)$} & \multicolumn{3}{|c|}{ Total carbon (g kg-1) } & \multicolumn{3}{|c|}{ Total Nitrogen (g kg-1) } & \multicolumn{3}{|c|}{$\mathrm{C} / \mathrm{N}$ ratio } \\
\hline & $\begin{array}{c}0^{\text {th }} \\
\text { day }\end{array}$ & $\begin{array}{l}30^{\text {th }} \\
\text { day }\end{array}$ & $\begin{array}{l}60^{\text {th }} \\
\text { day }\end{array}$ & $\begin{array}{c}0^{\text {th }} \\
\text { day }\end{array}$ & $\begin{array}{l}30^{\text {th }} \\
\text { day }\end{array}$ & $\begin{array}{l}60^{\text {th }} \\
\text { day }\end{array}$ & $\begin{array}{c}0^{\text {th }} \\
\text { day }\end{array}$ & $\begin{array}{l}30^{\text {th }} \\
\text { day }\end{array}$ & $\begin{array}{l}60^{\text {th }} \\
\text { day }\end{array}$ & $\begin{array}{c}0^{\text {th }} \\
\text { day }\end{array}$ & $\begin{array}{l}30^{\text {th }} \\
\text { day }\end{array}$ & $\begin{array}{l}60^{\text {th }} \\
\text { day }\end{array}$ & $\begin{array}{c}0^{\text {th }} \\
\text { day }\end{array}$ & $\begin{array}{l}30^{\text {th }} \\
\text { day }\end{array}$ & $\begin{array}{l}60^{\text {th }} \\
\text { day }\end{array}$ \\
\hline $\mathrm{T} 1$ & 6.80 & 8.90 & 8.00 & 3.29 & 3.50 & 3.59 & 440 & 289 & 190 & 31.2 & 15.9 & 16.0 & 14.0:1 & 18.1:1 & 11.8:1 \\
\hline $\mathrm{T} 2$ & 7.40 & 8.40 & 7.60 & 1.26 & 1.41 & 1.45 & 449 & 320 & 229 & 16.9 & 18.4 & 18.7 & $26.5: 1$ & 17.3:1 & 12.2:1 \\
\hline $\mathrm{T} 3$ & 7.30 & 8.00 & 7.50 & 1.15 & 1.25 & 1.29 & 432 & 381 & 225 & 16.7 & 18.7 & 19.9 & 25.8:1 & $20.4: 1$ & 11.3:1 \\
\hline $\mathrm{T} 4$ & 7.40 & 8.20 & 7.50 & 1.28 & 1.39 & 1.44 & 455 & 320 & 260 & 16.4 & 18.2 & 18.5 & $27.7: 1$ & 17.5:1 & 14.0:1 \\
\hline $\mathrm{T} 5$ & 7.20 & 8.40 & 7.80 & 1.23 & 1.35 & 1.43 & 436 & 291 & 239 & 16.4 & 17.4 & 18.4 & $26.5: 1$ & $16.7: 1$ & 13.0:1 \\
\hline T6 & 7.40 & 8.10 & 7.50 & 1.10 & 1.22 & 1.27 & 432 & 320 & 233 & 16.4 & 18.6 & 19.9 & 26.3:1 & $17.2: 1$ & $11.7: 1$ \\
\hline $\mathrm{T} 7$ & 7.40 & 8.10 & 7.50 & 1.25 & 1.38 & 1.41 & 431 & 322 & 258 & 16.5 & 18.4 & 18.7 & 26.1:1 & 17.5:1 & 13.8:1 \\
\hline $\operatorname{LSD}(0.05)$ & 0.39 & 0.45 & 0.58 & 0.05 & 0.07 & 0.09 & NS & 18.1 & 13.4 & 0.72 & 0.45 & 0.49 & - & - & - \\
\hline
\end{tabular}

Values are means of four observations. Results are expressed in air dry weight basis. NS-Not Significant

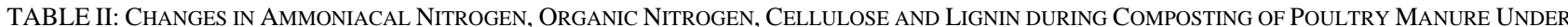
BENCH SCALE COMPOSTING

\begin{tabular}{|c|c|c|c|c|c|c|c|c|c|c|c|c|}
\hline \multirow{2}{*}{ Treatments } & \multicolumn{3}{|c|}{ Ammoniacal Nitrogen $\left(\mathrm{g} \mathrm{kg}^{-1}\right)$} & \multicolumn{3}{|c|}{ Organic Nitrogen $\left(\mathrm{g} \mathrm{kg}^{-1}\right)$} & \multicolumn{3}{|c|}{ Cellulose content $\left(\mathrm{g} \mathrm{kg}^{-1}\right)$} & \multicolumn{3}{|c|}{ Lignin content $\left(\mathrm{g} \mathrm{kg}^{-1}\right)$} \\
\hline & $0^{\text {th }}$ day & $30^{\text {th }}$ & $60^{\text {th }}$ day & $0^{\text {th }}$ day & $30^{\text {th }}$ & $60^{\text {th }}$ day & $0^{\text {th }}$ day & $30^{\text {th }}$ day & $60^{\text {th }}$ day & $0^{\text {th }}$ day & $30^{\text {th }}$ day & $60^{\text {th }}$ day \\
\hline $\mathrm{T}_{1}$ & 1.6 & 4.4 & 7.5 & 20.2 & 6.5 & 4.0 & 198 & 120 & 42 & 116 & 105 & 49 \\
\hline $\mathrm{T}_{2}$ & 2.1 & 7.0 & 9.0 & 12.5 & 7.5 & 5.2 & 196.2 & 151.6 & 101.6 & 131.6 & 122.0 & 56.2 \\
\hline $\mathrm{T}_{3}$ & 2.3 & 7.5 & 9.6 & 12.9 & 7.7 & 5.4 & 337.6 & 286.3 & 151.2 & 441.6 & 286.2 & 191.6 \\
\hline $\mathrm{T}_{4}$ & 2.4 & 5.7 & 8.6 & 12.2 & 7.2 & 5.0 & 291.6 & 176.2 & 141.2 & 291.6 & 241.6 & 186.2 \\
\hline $\mathrm{T}_{5}$ & 2.5 & 7.1 & 8.5 & 12.0 & 7.0 & 4.7 & 231.6 & 191.6 & 151.2 & 216.2 & 146.2 & 61.2 \\
\hline $\mathrm{T}_{6}$ & 2.6 & 7.7 & 9.9 & 12.6 & 7.2 & 5.1 & 311.6 & 171.6 & 140.2 & 449.6 & 301.6 & 201.2 \\
\hline $\mathrm{T}_{7}$ & 2.3 & 5.9 & 8.9 & 12.4 & 6.7 & 4.8 & 271.2 & 191.6 & 156.3 & 301.2 & 231.2 & 180.6 \\
\hline $\operatorname{LSD}(0.05)$ & 0.11 & 0.34 & 0.48 & 0.28 & 0.25 & 0.12 & 5.5 & 4.3 & 8.1 & 19.2 & 11.6 & 5.7 \\
\hline
\end{tabular}

Values are means of four observations. Results are expressed in air dry weight basis

TABlE III: Changes in Ph, Ec, Total CARbon, Total Nitrogen And C/N RAtio during Composting Of Poultry Manure Under LARge Scale COMPOSTING

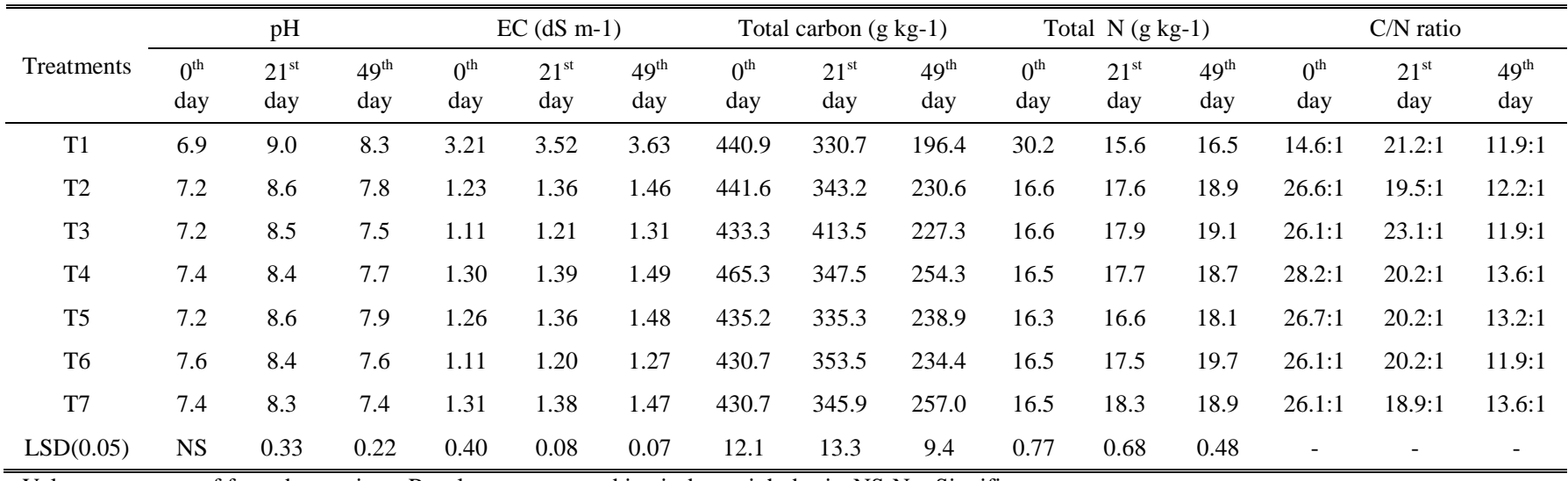




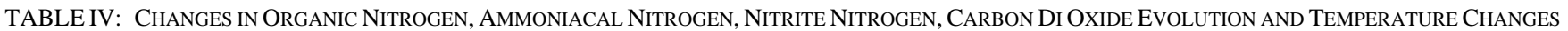
DURING COMPOSTING OF POULTRY MANURE UNDER LARGE SCALE COMPOSTING

\begin{tabular}{|c|c|c|c|c|c|c|c|c|c|c|c|c|c|c|c|}
\hline \multirow{2}{*}{ Treatments } & \multicolumn{3}{|c|}{$\begin{array}{l}\text { Organic Nitrogen (per } \\
\text { cent) }\end{array}$} & \multicolumn{3}{|c|}{$\begin{array}{l}\text { Ammoniacal Nitrogen } \\
\text { (per cent) }\end{array}$} & \multicolumn{3}{|c|}{$\begin{array}{l}\text { Nitrite Nitrogen (per } \\
\text { cent) }\end{array}$} & \multicolumn{3}{|c|}{$\begin{array}{l}\text { CO2 evolution (mg of CO2 } 100 \\
\text { g-1 of compost day-1) }\end{array}$} & \multicolumn{3}{|c|}{ Temperature $\left({ }^{\circ} \mathrm{C}\right)$} \\
\hline & $\begin{array}{c}0^{\text {th }} \\
\text { day }\end{array}$ & $\begin{array}{l}21^{\text {st }} \\
\text { day }\end{array}$ & $\begin{array}{l}49^{\text {th }} \\
\text { day }\end{array}$ & $\begin{array}{c}0^{\text {th }} \\
\text { day }\end{array}$ & $\begin{array}{l}21^{\text {st }} \\
\text { day }\end{array}$ & $\begin{array}{l}49^{\text {th }} \\
\text { day }\end{array}$ & $\begin{array}{c}0^{\text {th }} \\
\text { day }\end{array}$ & $\begin{array}{l}21^{\text {st }} \\
\text { day }\end{array}$ & $\begin{array}{l}49^{\text {th }} \\
\text { day }\end{array}$ & $0^{\text {th }}$ day & $21^{\text {st }}$ day & $49^{\text {th }}$ day & $\begin{array}{c}0^{\text {th }} \\
\text { day }\end{array}$ & $\begin{array}{l}21^{\text {st }} \\
\text { day }\end{array}$ & $\begin{array}{l}49^{\text {th }} \\
\text { day }\end{array}$ \\
\hline $\mathrm{T} 1$ & 21.1 & 7.2 & 4.3 & 1.3 & 4.3 & 7.2 & 0.7 & 1.2 & 0.6 & 5.1 & 8.4 & 4.6 & 30 & 54 & 32 \\
\hline $\mathrm{T} 2$ & 12.2 & 7.6 & 5.1 & 2.3 & 6.3 & 8.6 & 0.7 & 1.0 & 0.7 & 5.4 & 9.2 & 5.8 & 32 & 62 & 36 \\
\hline T3 & 12.6 & 8.1 & 5.2 & 2.3 & 6.3 & 9.2 & 0.6 & 1.2 & 0.7 & 5.0 & 9.6 & 5.6 & 32 & 59 & 34 \\
\hline $\mathrm{T} 4$ & 12.0 & 7.5 & 5.0 & 2.6 & 5.6 & 8.6 & 0.7 & 0.7 & 0.6 & 5.3 & 9.2 & 5.6 & 32 & 48 & 36 \\
\hline T5 & 12.3 & 7.6 & 5.0 & 2.8 & 5.8 & 8.1 & 0.7 & 0.7 & 0.4 & 4.6 & 9.2 & 5.1 & 33 & 48 & 33 \\
\hline T6 & 12.6 & 7.7 & 5.1 & 2.6 & 5.6 & 8.9 & 0.7 & 1.0 & 0.6 & 5.3 & 9.6 & 5.6 & 33 & 64 & 35 \\
\hline $\mathrm{T} 7$ & 12.8 & 7.5 & 5.1 & 2.1 & 6.1 & 8.5 & 0.7 & 0.8 & 0.7 & 5.3 & 8.6 & 5.1 & 33 & 64 & 35 \\
\hline $\operatorname{LSD}(0.05)$ & 0.75 & 0.42 & 0.13 & 0.05 & 0.99 & 0.21 & 0.01 & 0.03 & 0.03 & 0.14 & 0.51 & 0.19 & 8.7 & 4.0 & 1.3 \\
\hline
\end{tabular}

Values are means of four observations. Results are expressed in air dry weight basis

TABLE V: CHANGES IN ENZYME ACTIVITIES AND CRUdE PROTEIN DURING COMPOSTING OF POULTRY MANURE UNDER LARGE SCALE COMPOSTING

\begin{tabular}{|c|c|c|c|c|c|c|c|c|c|c|c|c|c|c|c|}
\hline \multirow[t]{2}{*}{ Treatments } & \multicolumn{3}{|c|}{$\begin{array}{l}\text { Invertase ( } \mu \text { g of reducing } \\
\text { sugar released h-1 g-1 dry } \\
\text { compost) }\end{array}$} & \multicolumn{3}{|c|}{$\begin{array}{l}\text { Phosphatase ( } \mu \text { g phenol } \\
\text { released h-1 g-1 dry } \\
\text { compost) }\end{array}$} & \multicolumn{3}{|c|}{$\begin{array}{l}\text { Urease ( } \mu \text { g NH3 released } \\
\text { h-1 g-1 dry compost) }\end{array}$} & \multicolumn{3}{|c|}{$\begin{array}{c}\text { Cellulase ( } \mu \text { g of reducing } \\
\text { sugar released h-1 g-1 dry } \\
\text { compost) }\end{array}$} & \multicolumn{3}{|c|}{$\begin{array}{l}\text { Crude protein } \\
\text { (per cent) }\end{array}$} \\
\hline & Initial & $21^{\text {st }}$ & $\begin{array}{l}49^{\text {th }} \\
\text { day }\end{array}$ & Initial & $\begin{array}{l}21^{\text {st }} \\
\text { day }\end{array}$ & $\begin{array}{l}49^{\text {th }} \\
\text { day }\end{array}$ & Initial & $\begin{array}{l}21^{\text {st }} \\
\text { day }\end{array}$ & $\begin{array}{l}49^{\text {th }} \\
\text { day }\end{array}$ & Initial & $\begin{array}{l}21^{\text {st }} \\
\text { day }\end{array}$ & $\begin{array}{l}49^{\text {th }} \\
\text { day }\end{array}$ & Initial & $\begin{array}{l}21^{\text {st }} \\
\text { day }\end{array}$ & $\begin{array}{l}49^{\text {th }} \\
\text { day }\end{array}$ \\
\hline $\mathrm{T} 1$ & 105 & 335 & 98 & 9.5 & 21.8 & 30.2 & 365 & 105 & 38 & 62 & 86 & 86 & 18.9 & 9.8 & 10.3 \\
\hline $\mathrm{T} 2$ & 112 & 355 & 109 & 9.2 & 22.7 & 34.3 & 265 & 70 & 38 & 118 & 147 & 218 & 10.4 & 11.0 & 11.8 \\
\hline T3 & 122 & 375 & 127 & 10.2 & 24.1 & 35.8 & 235 & 55 & 34 & 127 & 156 & 232 & 10.4 & 11.2 & 11.9 \\
\hline $\mathrm{T} 4$ & 107 & 332 & 101 & 8.1 & 21.4 & 32.6 & 260 & 85 & 54 & 105 & 132 & 200 & 10.3 & 11.1 & 11.7 \\
\hline T5 & 107 & 349 & 102 & 8.7 & 22.1 & 33.7 & 275 & 85 & 41 & 115 & 140 & 214 & 10.2 & 10.4 & 11.3 \\
\hline T6 & 106 & 368 & 114 & 9.7 & 33.2 & 34.2 & 265 & 65 & 38 & 125 & 150 & 225 & 10.3 & 11.0 & 12.3 \\
\hline $\mathrm{T} 7$ & 116 & 342 & 96 & 8.9 & 22.4 & 33.9 & 265 & 92 & 49 & 109 & 135 & 209 & 10.3 & 11.4 & 11.8 \\
\hline $\operatorname{LSD}(0.05)$ & 6.5 & NS & 2.7 & 0.34 & 0.43 & 0.89 & 60.6 & 26.1 & 7.5 & 6.1 & 3.3 & 4.1 & - & - & - \\
\hline
\end{tabular}

Values are means of four observations. Results are expressed in air dry weight basis. NS-Not Significant

\section{CONCLUSION}

The experimental results confirmed that the carbon content and $\mathrm{C} / \mathrm{N}$ ratio of the compost were reduced as the composting process proceeded. The nutrient content of poultry compost $(\mathrm{N}, \mathrm{P}$ and $\mathrm{K})$ was increased with the advancement of composting. The coir pith mixed poultry composts recorded high nitrogen $\left(19.7 \mathrm{~g} \mathrm{~kg}^{-1}\right)$ and potassium content $\left(13.9 \mathrm{~g} \mathrm{~kg}^{-1}\right)$ whereas coir pith and rock phosphate mixed poultry compost recorded high phosphorus content $\left(20.1 \mathrm{~g} \mathrm{~kg}^{-1}\right)$. The poultry waste compost (control) recorded high EC (3.63 dS $\mathrm{m}^{-1}$ ) value when compared to coir pith and paddy straw mixed compost, it proves the importance of mixing carbonaceous wastes while making poultry compost. Coir pith mixed poultry compost recorded the least ammonia loss. Matured compost had no inhibitory effect on germination of different seeds tested for phytotoxicity. So locally available indigenous carbonaceous wastes materials can effectively be utilized for making poultry compost. The way of making compost by mixing poultry manure with carbonaceous wastes not only reduces the ammonia loss but also solve the disposal problem of carbonaceous wastes.

\section{ACKNOWLEDGMENT}

The authors acknowledge sincerely University Grants Commission for the financial support to carryout this research work in a successful manner.

\section{REFERENCES}

[1] S. Mahimairaja, N. S. Bolan, M. J. Hedley, and A. N. MacGregor, "Losses and transformation of nitrogen during composting of poultry manure with different amendments: An incubation experiment," Bioresour. Technology, vol. 47, pp. 265 - 273, 1994.

[2] M. Prasanthrajan, P. Doraisamy, and S. Avudainayagam, "Screening of suitable indigenous carbon source for nitrogen conservation in poultry manure, "in proc. National symposium on recent trends in applied biology, Coimbatore, 2004, pp. 158-159.

[3] C. M. Reynolds, and D. C. Wolf, "Effect of soil moisture and air relative humidity on ammonia volatilization from surface-applied urea," J. of Soil Science, vol. 143, pp. 144-152, 1987.

[4] C. F. Michel Jr, C. A. Reddy, and L. J. Forney, "Yard waste composting: Studies using different mixes of leaves and grass in a laboratory scale system, “Comp. Science. and Utilization, vol. 1(3), pp. 85-96, 1993.

[5] R. C. Hansen, H. M. Keener, and H. A. J. Hoitink, "Poultry manure composting: An exploratory study," in Transactions of American society of agricultural engineers, vol. 36, pp. 2151-2157, 1989.

[6] R. Nodar, M. J. Acea , and T. Carballas, "Microbial population of poultry pine-sawdust litter,” Biol. Wastes, vol. 33, pp. 295-306, 1990.

[7] M. Kithome, J. W. Paul, and A. A. Bomke, "Reducing nitrogen losses manure using adsorbents and chemical amenders," J. of Environ. Quality, vol. 28, pp. 194-201, 1999.

[8] S. Mahimairaja, N. S. Bolan, and M. J. Hedley, Agronomic effectiveness of poultry manure composts. Commun. Soil Plant Anal.ysis, vol. 26, pp. 1843-1861, 1995.

[9] C. P. Singh, and A. Amberger, "Solubilization and availability of phosphorus during decomposition of rock phosphate enriched straw and urine,” J. of Biol. Agric. Horticulrure, vol. 7, pp. 261-269, 1991.

[10] C. Gaur, Microbial technology for composting of agricultural residues of improved methods, Indian Council of Agricultural Research, New Delhi, 1999. 
[11] C. L. Davis, S. A. Hinch, C. J. Donkis, and P. J. Germishuizen, "Changes in microbial population numbers during the composting of pine bark,” Bioresour. Technology, vol. 39, pp. 85-92, 1992.

[12] F. Stutzenberger, "Cellulase production by Thermononospora curvata isolated from municipal solid waste compost," Appl. Environ. Microbiology, vol. 22, pp. 147-152, 1971

[13] G. L. Francis, J. M. Hawthorne, and G.R. Storer, "Factors affecting the activity of cellulose isolated from the rumen digest of sheep," Appl. Environ. Microbiology, vol. 36, pp. 643-649, 1978.

[14] B. Godden, M. Penninckx, A. Pierard, and R. Robert Lannoye, "Evaluation of enzyme activities and microbial populations during composting cattle manure,” Eur. J. of Appl. Microbial. Biotechnology, vol. 17. pp. 306-310, 1983.

[15] W. K. Kim, and P. H. Patterson, "Effect of minerals on activity of microbial uricase to reduce ammonia volatilization in poultry manure. Poult. Science, vol. 82, pp. 223-231, 2003.

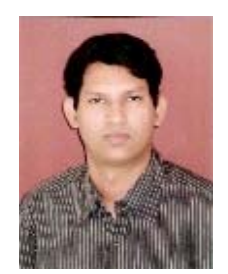

Prasanthrajan Mohan received his bachelor degree in Agriculture from Tamil Nadu Agricultural University, Coimbatore, India in 1998, master's degree and Doctor of Philosophy in Environmental Science from Tamil Nadu Agricultural University in 2001 and 2004 respectively. He is presently working as Assistan Professor in Department of Environmental Science, Tamil Nadu Agricultural University, Coimbatore, India and Joined Institute in 2004. His main research interests bioremediation, use of nano particles for pollutant removal. 